\title{
Carcass quality of buffalo (Bubalus bubalis) finished in silvopastoral system in the Eastern Amazon, Brazil
}

\author{
[Qualidade da carcaça de búfalos (Bubalus bubalis) terminados em sistema \\ silvipastoril na Amazônia Oriental, Brasil]
}

\author{
M.R.S. Peixoto ${ }^{1}$, J.B. Lourenço Junior ${ }^{2}$, C. Faturi ${ }^{3}$, A.R. Garcia ${ }^{4}$, B.S. Nahúm ${ }^{4}$, \\ L.F.H. Lourenço ${ }^{2}$, L.H. Meller ${ }^{2}$, K.C.C. Oliveira ${ }^{5}$ \\ ${ }^{1}$ Instituto Federal de Educação - IFPA - Castanhal, PA \\ ${ }^{2}$ Universidade Federal do Pará, PA \\ ${ }^{3}$ Universidade Federal Rural da Amazonia - AM \\ ${ }^{4}$ Embrapa Eastern Amazon - AM \\ ${ }^{5}$ Aluno de pós-graduação - Universidade Federal do Pará - PA
}

\begin{abstract}
The influence of the diet on the quality of buffalo (Bubalus bubalis) carcasses of crossbred Murrah and Mediterranean, concentrate fed on traditional (corn/soybean) or on agro-industrial residues (palm oil and coconut cakes) was studied. The animals were sacrificed in a slaughterhouse, and physical and physicalchemical analyses in the carcasses were carried out after 24 hours, and instrumental color and texture analyses of the Longissimus dorsi were carried out 48 hours after cooling. The animals supplemented with palm oil cake had better carcass conformation and fat trim, and differences $(\mathrm{P}<0.05)$ in the percentage of fat in the carcass fat thickness and coverage were observed.
\end{abstract}

Keywords: buffalo, feed efficiency, agroforestry systems, oil palm cake, coconut cake

\section{RESUMO}

Avaliou-se a influência da dieta sobre a qualidade de carcaça de búfalos mestiços das raças Murrahe Mediterrâneo, alimentados com concentrado tradicional - milho/soja - ou resíduos agroindustriais tortas de coco e dendê. Os animais foram sacrificados em abatedouro comercial, e realizadas análises físicas e físico-químicas na carcaça, após 24 horas, e de cor e textura instrumentais no músculo Longissimus dorsi, após 48 horas de resfriamento. Os animais suplementados com a torta de dendê adquiriram melhor conformação de carcaça e acabamento de gordura, e observaram-se diferenças $(P<0,05)$ no percentual de gordura na carcaça e na espessura de gordura de cobertura.

Palavras-chave: bufalo, eficiência alimentar, sistema agroflorestal, torta de dendê, torta de coco

\section{INTRODUCTION}

The Brazilian buffalo herds in the northern region and in the state of Para, from 1970 to 2006, experienced increases, respectively, $87.7 \%, 89.3 \%$ and $84.2 \%$. In 2008 , the northern region of Brazil contained $62.8 \%$ of the national buffalo herd (IBGE, 2010). The various agrosilvopastoral systems, among which silvopastoral stands out, could be used to raise buffalo in previously altered areas, in addition to adding value to the land through the forestry component, enabling the improved cycling of nutrients, increasing the comfort level of the herd and maximizing the sustainable use of the land (Lourenço Júnior and Garcia, 2006).

Some research indicates that an increase in concentrated fodder in the diet improves yield (Silva et al., 2006), finishing (Costa et al., 2009), shaping (Vaz et al., 2005), physical composition (Gesualdi Jr. et al., 2000) and the yield of commercial cuts from the carcass (Ribeiro et al.,

Recebido em 18 de agosto de 2011

Aceito em 6 de março de 2012

E-mail: reginajoele@hotmail.com 
2001). The food supplementation with byproducts from the agro-industry provides an inexpensive alternative to fulfill the nutritional demands of buffalo during the production of meat.

Among the factors that influence the choice of a byproduct for ruminant feed are the amount available, the proximity to the source and place of consumption, the nutritional characteristics, the cost of transport, conditioning and storage requirements. However, researches on characteristics of carcasses and on meat of buffalo cattle that were raised under different management conditions and feeding systems are missing or contradictory (Jorge et al., 2008). Therefore, given the increasing importance of buffalo farming in the local scene, this study aimed to evaluate the influence of the diet on the quality of the carcasse of crossbred Murrah and Mediterranean buffaloes, fed traditional (corn/soybean) or waste agro-industry residues (palm oil and coconut cakes).

\section{MATERIAL AND METHODS}

The experiment was conducted in the Silvopastoral System (SPS) of the Animal Research Unit "Senador Álvaro Adolpho". The research unit is located in the Embrapa Eastern Amazon, Belém, PA ( $1^{\circ} 28^{\prime} \mathrm{S}$ and $\left.48^{\circ} 27^{\prime} \mathrm{W}\right)$.

The Silvopastoral System consists of an area of 5.4ha, divided into five paddocks. There is a central installation, composed of a covered arena, a drinking trough and a feeder for mineral supplementation (Castro, 2005). The area is enclosed by perimeter fences and electric barriers, with two straight wire cables. African mahogany (Khaya ivorensis) and indian neem (Azadirachta indica) were planted in 2002, on a $4 \mathrm{~m}$ grid. The trees shade about $20 \%$ of the area. The system has mombaça grass (Panicum maximum cv mombaça), managed through intensive rotation, in a 30-day cycle, with six days of occupation and 24-days of rest, and initial and final occupation rates of 3.0AU and 4.5AU, respectively. Pastures are plowed, followed by clod breaking and level harrowing. The land is then fertilized with $100 \mathrm{~kg}$ of $\mathrm{P}_{2} \mathrm{O}_{5} \mathrm{ha}^{-1}$ in the form of natural reactive phosphate (Oliveira et al., 2010).

The experiment was conducted between April and December. A herd of 15 male buffalo, Murrah and Mediterranean crossbred, were fed once a day, in an amount of $1 \%$ of their body weight. The three types of feed were prepared from agro-industrial by-products (Table 1), and the compositions of the feed are shown in Table 2. Each treatment consisted of five animals that were fed every morning in individual stalls to control consumption by weighing the food offered and leftovers. The animals were fed every morning in individual bays in order to control consumption.

Table 1. Proportion of components in each experimental diet with buffaloes

\begin{tabular}{lccc}
\hline Component $(\%)$ & Corn & Coconut & Palm oil \\
\hline Corn Pie & 63 & 19 & 2 \\
Coconut cake & - & 70 & - \\
Palm oil cake & - & - & 70 \\
Soybean bran & 25 & - & 15 \\
Wheat bran & 12 & 11 & 13 \\
\hline
\end{tabular}

Table 2. Chemical composition of diets used for buffaloes

\begin{tabular}{lccc}
\hline Component & Corn & Coconut & Palm oil \\
\hline Dry mater (\%) & 87.13 & 91.63 & 90.97 \\
Crude protein (CP) (\%) & 18.46 & 18.21 & 16.95 \\
Neutral detergent fiber (\%) & 19.83 & 45.42 & 63.87 \\
Acid detergent fiber (\%) & 11.65 & 28.84 & 35.84 \\
Ether extract (\%) & 3.64 & 8.87 & 11.82 \\
\hline
\end{tabular}


After finishing the silvopastoral system pahse the animals were weighed after 14 hours of fasting. They were transported in 30 minutes to a State Inspected slaughterhouse situated in Belém, Para State, Brazil. The animals were kept on a hydric diet for an additional 16h. Animals were weighed again (live animal weight - LAW), and slaughtered following the normal procedures of the slaughterhouse, according to the norms of the Industrial and Sanitary Inspection Regulations for Animal Products- RIISPOA (Brasil, 1997). Afterwards, the carcasses were cooled for $24 \mathrm{~h}$ at a temperature of $2-4^{\circ} \mathrm{C}$.

Measurements of carcass length (CC), arm length and leg length, were taken with a tape measure after the carcass was cooled. Carcass length was measured on the ventral surface, from the pubic bone to the anterior rim of the first rib.

The left half carcass was divided into forequarter and hindquarter, beyond the spare ribs, which includes the abdominal muscles, from the sixth rib. After separation, the quarters were weighted to calculate the percentage over the cold halfcarcass.

A cut was made in the right half of the carcass between the $12^{\text {th }}$ and the $13^{\text {th }}$ ribs in order to expose the Longissimus dorsi muscle and measure the eye loin area (AOL). To measure the AOL, an outline was drawn on vegetal paper. The thickness of the fat covering the AOL was measured (EGC) with a stainless steel caliper. Marbling was evaluated on an 18-point scale, using the categories of light, small, average, moderate and abundant (Müller, 1987). From the data obtained above, carcass composition variables were estimated, including bone, muscle and fat percentages (Felício, 1997).

The $\mathrm{pH}$ values and temperatures of the carcasses were determined using a portable penetration potentiometer, HANNA brand, model H99163. The readings were taken at a depth of $5 \mathrm{~cm}$ in the Longissimus dorsi muscle, between the $10^{\text {th }}$ and $11^{\text {th }}$ ribs. Two $\mathrm{pH}$ readings were taken postslaughter, one at 45 minutes (initial $\mathrm{pH}$ ) and one at 24 hours (final $\mathrm{pH}$ ).

To evaluate shear force, six cylinders of $1.27 \mathrm{~cm}$ per steak were cut using a puncher in a texture analyzer (Brookfield QTS 25 brand) with a Warner-Bratzler blade, $48 \mathrm{~h}$ after slaughter (Wheeler et al., 1995). The equipment was calibrated with a $5 \mathrm{~kg}$ weight, with a blade speed of $200 \mathrm{~mm} / \mathrm{minute}$, set at $25.0 \mathrm{~mm}$ from the platform. The sheer force of each steak, expressed in kgf, was established by the average cut force of the six cylinders.

The color characteristic was established objectively by measurements of L* (luminosity), $\mathrm{a}^{*}$ (red/green intensity) and $\mathrm{b}^{*}$ (yellow/blue intensity) using a CIELAB System with D65 illuminant. The equipment was set to an $8^{\circ}$ angle of vision and an observer pattern of $10^{\circ}$. Measurements were taken 48 hours after slaughter using a portable Minolta CR 400 spectrophotometer, equipped with an accessory to protect against humidity. The measurements were conducted 30 minutes after the opening of the packages and the exposure of the cuts to air under refrigeration. The data shown are the average of six readings, obtained in different but standardized positions of the same muscle.

The experimental procedure was completely randomized, with each animal representing one experimental unit. The normality of the data distribution was tested; since all the variables followed the normality premise, there was no need to transform the data. For analysis of the effect of supplement type (corn, coconut or palm oil), the data were submitted to analysis of variance and t-test using a SAS - statistical package. Significance was set at $5 \%$.

\section{RESULTS AND DISCUSSION}

During the supplementation stage, the average weight gain of the animals was $1.0 \mathrm{~kg} /$ day $( \pm 0.3)$, with no statistical difference among treatments. The quantitative characteristics of the animal carcasses are shown in Table 3 according to the type of supplementation. We observed that the diets had little influence on the quantitative variables. These results may be due to the similar slaughter weights of the animals, because quantitative variables are highly correlated with carcass weight (Euclides Filho et al., 1997). However, there was an influence on carcass length and composition and on the meat and fat percentage $(\mathrm{P}<0.05)$. 
Table 3. Mean, standard deviation and coefficient of variation for quantitative characteristics of the buffalo carcass according to supplementation/diet

\begin{tabular}{lcccc} 
Variable & Corn & Coconut & Palm oil & $\begin{array}{c}\text { CV } \\
(\%)\end{array}$ \\
\hline Live animal weight, kg & $640.0 \mathrm{a} \pm 27.6$ & $645.8 \mathrm{a} \pm 28.3$ & $665.0 \mathrm{a} \pm 13.1$ & 7.86 \\
Hot carcass weight, kg & $328.0 \mathrm{a} \pm 2.7$ & $318.2 \mathrm{a} \pm 12.1$ & $314.0 \mathrm{a} \pm 36.4$ & 11.27 \\
Carcass yield, \% & $59.2 \mathrm{a} \pm 2.5$ & $58.7 \mathrm{a} \pm 1.1$ & $57.2 \mathrm{a} \pm 0.9$ & 4.72 \\
Carcass length, cm & $146.0 \mathrm{~b} \pm 2.8$ & $157.0 \mathrm{a} \pm 4,1$ & $149.0 \mathrm{~b} \pm 8.7$ & 3.61 \\
Leg length, cm & $84.5 \mathrm{a} \pm 0.7$ & $86.6 \mathrm{a} \pm 1.5$ & $86.7 \mathrm{a} \pm 0.6$ & 2.57 \\
Arm length, cm & $44.5 \mathrm{a} \pm 2.1$ & $44.2 \mathrm{a} \pm 1.5$ & $45.0 \mathrm{a} \pm 1.0$ & 3.92 \\
Hindquarter weigth, kg & $130.1 \mathrm{a} \pm 31.8$ & $125.5 \mathrm{a} \pm 4.6$ & $117.5 \mathrm{a} \pm 11.7$ & 17.32 \\
Hindquarter, \% & $39.4 \mathrm{a} \pm 4.5$ & $39.2 \mathrm{a} \pm 1.3$ & $37.3 \mathrm{a} \pm 0.7$ & 7.32 \\
Spare ribs weigth, kg & $34.8 \mathrm{a} \pm 5.6$ & $33.8 \mathrm{a} \pm 4.7$ & $36.2 \mathrm{a} \pm 5.5$ & 12.99 \\
Spare ribs, \% & $10.6 \mathrm{a} \pm 0,3$ & $10.7 \mathrm{a} \pm 1,0$ & $11.5 \mathrm{a} \pm 0.6$ & 9.77 \\
Forequarter weigth, kg & $162.9 \mathrm{a} \pm 6.2$ & $162.8 \mathrm{a} \pm 18.4$ & $161.5 \mathrm{a} \pm 19.9$ & 9.77 \\
Forequarter, \% & $50.0 \mathrm{a} \pm 4.8$ & $51.3 \mathrm{a} \pm 3.7$ & $51.2 \mathrm{a} \pm 0.8$ & 6.68 \\
Meat, \% & $69.5 \mathrm{a} \pm 1.8$ & $69.6 \mathrm{a} \pm 1.1$ & $66.5 \mathrm{~b} \pm 0.8$ & 1.73 \\
Fat, \% & $14.9 \mathrm{~b} \pm 3.5$ & $13.4 \mathrm{~b} \pm 1.6$ & $17.1 \mathrm{a} \pm 1.5$ & 13.23 \\
Bones, \% & $15.6 \mathrm{a} \pm 1.7$ & $17.0 \mathrm{a} \pm 1.2$ & $16.5 \mathrm{a} \pm 0.8$ & 7.31 \\
Value edible portion / bones & $5.4 \mathrm{a} \pm 0.7$ & $4.9 \mathrm{a} \pm 0,4$ & $5.1 \mathrm{a} \pm 0,3$ & 9.08 \\
\hline
\end{tabular}

Means followed by different letters in the same row, differ significantly among themselves $(\mathrm{P}<0.05)$.

No significant differences were found in carcass yield for the different dietary supplements. The similar slaughter weights and the identical procedures used in the pre-slaughter of experimental animals in the three types of treatment should be noted.

According to Restle et al. (2000), carcass yield is influenced by the number of hours of fasting the animals are submitted to, the type of diet and genetic factors, among other variables. Missio et al. (2010) did not observe an influence of forage levels on the weight or the yield of hot and cold carcasses (P>0.05), whereas Restle et al. (2001) observed that, when the forage shows a high crossover rate, there is no difference in this variable among animals fed different levels of concentrated fodder.

The carcass yield values reported here were higher than those reported by Felício (1997) in the Jafarabadi breed of buffalo $(r=48.7 \%)$, slaughtered at 24 months with $400 \mathrm{~kg}$; by Jorge et al. (2005) at $49.4 \%$ in buffalo slaughtered at different stages of maturity; or by Oliveira et al. (1991) at $49.3 \%$ in confined buffalo. Research conducted by Franzolin and Silva (2001) found an average yield between $49.7 \%$ and $50.8 \%$. Compared to the data in the literature, the carcass yields reported in this study are good.
The absolute values of forequarter, hindquarter and ribcage cuts were not influenced $(\mathrm{P}>0.05)$ by the levels of forage in the diet. Franzolin and Silva (2001), who evaluated the effects of different levels of energy intake on the carcass characteristics of Mediterranean animals, reported average front quarter yields of $38.4 \%$ and strip-bone yields of $14.1 \%$. These authors concluded that buffalo have high potential for carcass production with good commercial cut yields when they are kept in confinement. However, Jorge et al. (2005) evaluated crossbred Mediterranean buffalo at different stages of maturity and reported averages for the special hindquarter between 44.97 and $47.67 \%$, less than those reported in the present research. Vaz et al. (2003) did not find any significant differences in the forequarter, strip-bone and special hindquarter yields in confined Mediterranean buffalo fed forage based on sugar cane or corn silage.

The highest fat percentage was found in the carcass of animals supplemented with palm oil $(\mathrm{P}<0.05)$. This result may be due to the composition of this agro-industrial by-product (Table 2). This product is rich in neutral detergent fiber, a precursor to the formation of triglycerides during ruminant fermentation, which is associated with a lowered meat percentage $(\mathrm{P}<0.05)$. The level of concentrated fodder in the diet did not influence $(\mathrm{P}>0.05)$ the 
physical composition of the carcass or the relationship between the tissues. This result may be attributed to the similar degree of development of the animals, because they were of similar average weights at the time of slaughter (Missio et al., 2010).

The deposition of animal fat is strongly correlated with slaughter weight (Restle et al., 1997), genetic background (Restle et al., 2000), age of the animal or energy density of the diet (Restle et al., 2001). Campo et al. (2008) observed that the fat proportion varied with the increase in average daily weight gain, due to the different energy densities of the diets. Gigli et al. (1994) evaluated buffalo fed diets of different caloric levels and concluded that the feed with the highest caloric value increased the total carcass fat, as well as inter-muscular and subcutaneous fat.

Table 4 shows the averages, standard deviations and coefficients of variance for the qualitative characteristics of the carcasses and meat from the experimental animals according to dietary supplementation. We observed a greater fat thickness and body fat percentages and a smaller percentage of available meat in the palm oil supplemented animals $(\mathrm{P}<0.05)$. These data indicate that an excess of subcutaneous and intermuscular fat deposition occurred because no significant differences were found in marbling in the Longissimus dorsi muscle, a process that is influenced by the high values of fiber and ether extract in the palm oil supplement (Table 2).

Table 4. Means, standard deviations and coefficient of variation for the quality characteristics of carcasses of buffaloes, according to supplementation/diet

\begin{tabular}{lcccc}
\hline Variable & Corn & Coconut & Palm oil & $(\%)$ \\
\hline pH initial & $7.09 \mathrm{a} \pm 0.1$ & $7.14 \mathrm{a} \pm 0.1$ & $6.99 \mathrm{a} \pm 0.1$ & 3.02 \\
pH finale & $6.14 \mathrm{a} \pm 0,1$ & $6.05 \mathrm{a} \pm 0.1$ & $6.11 \mathrm{a} \pm 0.1$ & 2.12 \\
Loin eye area, $\mathrm{cm}^{2}$ & $78.7 \mathrm{a} \pm 15.2$ & $68.9 \mathrm{a} \pm 6.2$ & $69.0 \mathrm{a} \pm 9.8$ & 12.83 \\
Fat thickness, mm & $3.2 \mathrm{~b} \pm 1.9$ & $3.2 \mathrm{~b} \pm 1.9$ & $8.3 \mathrm{a} \pm 1.1$ & 39.41 \\
Marbling, pontos & $7.0 \mathrm{a} \pm 5.6$ & $7.0 \mathrm{a} \pm 1.53$ & $9.3 \mathrm{a} \pm 0.6$ & 34.94 \\
Texture (Kgf) & $4.26 \mathrm{a} \pm 0.4$ & $3.92 \mathrm{a} \pm 0.3$ & $3.34 \mathrm{a} \pm 0.7$ & 10.01 \\
Color & & & & \\
$\mathrm{L}^{*}$ & $59.02 \mathrm{a} \pm 5.4$ & $60.88 \mathrm{a} \pm 5.5$ & $63.40 \mathrm{a} \pm 1.4$ & 7.86 \\
$\mathrm{a}^{*}$ & $26.55 \mathrm{a} \pm 2.6$ & $27.99 \mathrm{a} \pm 2.8$ & $28.06 \mathrm{a} \pm 2.6$ & 9.86 \\
$\mathrm{~b}^{*}$ & $12.29 \mathrm{a} \pm 2.0$ & $12.56 \mathrm{a} \pm 1.1$ & $13.56 \mathrm{a} \pm 0.5$ & 10.44 \\
\hline
\end{tabular}

Means followed by different letters in the same row differ significantly among themselves $(\mathrm{P}<0,005)$.

The thickness of the fat covering in animal carcasses in the corn and coconut treatments is close to $3 \mathrm{~mm}$, which is the lowest thickness that prevents meat from becoming dark upon exposure to cold temperatures. The animals supplemented with palm oil showed a thicker covering of fat, significantly different $(\mathrm{P}<0.05)$ from the other treatments.

The animals from the palm oil treatment group showed a high degree of marbling (9.3 points), significantly different from the other treatments $(\mathrm{P}<0.05)$. This result was surprising because buffalo meat is usually poorly marbled, with values between 3 and 4 points (Oliveira, 2005).

No significant differences were observed in the values of shear force among the treatments $(\mathrm{P}>0.05)$, which were lower than $5.0 \mathrm{kgf}$. Felício (1997) suggested that this is the maximum limit defining a soft meat. The lowest average $(\mathrm{FC}=3.34 \mathrm{kgf})$ was found in the palm oil treatment group. This result may be due to the higher fat percentages in the carcass, the greater fat thickness and the greater degree of marbling in the animals on palm oil supplementation.

Restle et al. (2000), when comparing animals slaughtered at 24 or 14 months of age, we observed that a $30 \%$ improvement in meat softness was correlated with a higher degree of marbling $(\mathrm{r}=0.28)$ and a higher percentage $(r=0.27)$ and total amount $(r=0.31)$ of fat. Meat softness is the factor that varies the most and is one of the attributes that is most desired by the consumer. Meat softness is determined by the subjective evaluation of texture through a sensory panel, or objectively in a texture-meter, which measures the shear force of superficial muscle fibers of meat. 
According to the objective color results, the Longissimus dorsi muscle is an intense red color. There were no significant differences among the treatments, perhaps due to the high $\mathrm{pH}$ of the meat. However, a linear increase in luminosity ( $\mathrm{L}^{*}$ value) was observed, which we attribute to the level of energy in the diet.

The color of meat is another characteristic that influences the purchasing decisions of the consumer. Darker colors have a negative effect, because they are associated with product deterioration, older animals or poor meat preservation. Improvements in color are important for commercialization, especially for supermarkets and butchers, where there is higher product output and consequently, larger capital turnover (Müller, 1987).

According to Missio et al. (2010), the levels of concentrated fodder in the diet have a linear influence on meat color, such that an increase in concentrated fodder improves meat color. Pacheco et al. (2005) observed a similarity in meat color of young and very young bullocks, a fact that was explained by the high speed of weight gain. Missio et al. (2010) observed positive correlations $(\mathrm{P}<0.001)$ between cold carcass weight and shaping, carcass length, leg length, arm perimeter and the percentage of muscle in the carcass.

Tables 5 and 6 show the correlations among the analyzed variables. A high correlation was observed between the weights of the forequarter, the hindquarter and the saw cuts, and the weights of the carcass $(\mathrm{P}<0.01)$. Those correlations suggest that good shapes are possible to achieve with heavier carcasses. A high negative correlation was observed between the fat content of the carcass and the muscularity of animals, i.e., the yield of the meat.

Table 5. Pearson correlation between body weight, carcass length and arm and leg measurements in the experimental animals SSP

\begin{tabular}{lccccccccc}
\hline & LAW & HCW & CCW & SPW & FQW & SRW & CL & AL & LL \\
\hline LAW & 1.00 & $0.68^{*}$ & $0.70^{* *}$ & 0.49 & 0.61 & $0.76^{* *}$ & 0.31 & 0.17 & 0.09 \\
HCW & & 1.00 & $1.00^{* *}$ & $0.95^{* *}$ & $0.74^{* *}$ & $0.54^{*}$ & 0.43 & -0.04 & 0.25 \\
CCW & & & 1.00 & $0.93^{* *}$ & $0.77^{* *}$ & $0.59^{*}$ & 0.42 & 0.00 & 0.26 \\
SPW & & & & 1.00 & $0.53^{*}$ & 0.33 & 0.41 & -0.04 & 0.22 \\
FQW & & & & & 1.00 & $0.69^{*}$ & 0.31 & 0.22 & 0.49 \\
SRW & & & & & & 1.00 & 0.13 & 0.23 & -0.03 \\
CL & & & & & & & 1.00 & -0.42 & 0.18 \\
AL & & & & & & & 1.00 & 0.36 \\
LL & & & & & & & & 1.00 \\
\hline
\end{tabular}

$* \mathrm{P}<0,05 ; * * \mathrm{P}<0,01 ;$ number of observations $=11 . \mathrm{LAW}=$ Live animal weight $; \mathrm{HCW}=$ Hot carcass weight; $\mathrm{CCW}$ $=$ Cold carcass weight; $\mathrm{SPW}=$ Spare ribs weigth $; \mathrm{FQW}=$ Forequarter weigth $; \mathrm{SRW}=$ Spare ribs weigth; $\mathrm{CL}=$ Carcass length; $\mathrm{AL}=$ Arm length; $\mathrm{LL}=\mathrm{Leg}$ length.

Table 6. Pearson correlation among carcass composition, fat thickness and marbling in rib-eye

\begin{tabular}{lcccccccc}
\hline & LAW & FT & Marb & MP & BP & FP & EP/B & EP \\
\hline LAW & 1.00 & $0.57 *$ & -0.29 & $-0.65^{*}$ & $-0.62^{*}$ & $0.80^{* *}$ & 0.40 & 0.62 \\
FT & & 1.00 & 0.16 & $-0.99^{* *}$ & -0.12 & $0.81^{* *}$ & -0.23 & 0.12 \\
Marb & & & 1.00 & -0.07 & $0.67 *$ & -0.28 & $-0.74 * *$ & -0.67 \\
MP & & & & 1.00 & 0.22 & -0.87 & 0.13 & -0.23 \\
BP & & & & & 1.00 & -0.67 & $-0.93 * *$ & $-1.00^{* *}$ \\
FP & & & & & & 1.00 & 0.37 & $0.68^{*}$ \\
EP/B & & & & & & & 1.00 & $0.93^{* *}$ \\
EP & & & & & & & & 1.00 \\
\hline
\end{tabular}

*P < 0,05; ** $\mathrm{P}<0,01$; number de observações = 11. LAW = Live animal weight; FT = Fat thickness; Marb = Marbling; MP = Meat Percentage; $\mathrm{BP}=$ Bone Percentage; FP = Fat Percentage $; \mathrm{EP} / \mathrm{B}=$ Value edible portion/bones; $\mathrm{EP}=$ Edible Portion 
According to Luchiari Filho (2000), the eye loin area (AOL) is also used as an indicator of carcass composition. The AOL and the edible portion of the carcass are positively associated; as the AOL increases, so does the edible portion and viceversa. The AOL is connected to the percentage of meat in the carcass, whereas the EGC is an indicator of the composition of the carcass, especially of the percentages of the edible portions and fat. Besides being an indicator of carcass composition and, especially, of meat yield, the EGC is associated with quality, as it protects the meat against the hardening associated with dehydration and cooling.

\section{CONCLUSIONS}

The inclusion of palm oil in the diet of buffalo put out to pasture in a silvopastoral system led to an increased percentage of fatty tissue in the carcass, an increased thickness of the fat covering and increased marbling. In addition, a smaller shear force was noted, indicating a softer meat product. Color was also improved, as indicated by the increase in luminosity. Those attributes are relevant for purchasing decisions made by the consumer.

\section{ACKNOWLEDGEMENTS}

Authors thank Federal Institute for Education, Science and Technology - IFPA, Embrapa Eastern Amazon (Animal Biotec Network; code 01.07.01.02.09.05), Federal Rural University of Amazônia-UFRA, Brazilian National Council for Scientific and Technological Development (CNPq; process 481837/2007-8) and CAPES/FAPESPA for financial support

\section{REFERENCES}

BRASIL. 1997. Ministério da Agricultura. Departamento Nacional de Inspeção de Produtos de Origem Animal. Regulamento da Inspeção Industrial e Sanitária de Produtos de Origem Animal - RIISPOA. Aprovado pelo decreto n 30691 de 29 de março de 1952, alterado pelo Decreto 1255 de 25 de junho de 1962. Alterado pelo Decreto 2244 de 04/06/1997. Brasília-DF.

CAMPO, M.; BRITO, G.; LIMA, J.M.S. et al. Effects of feeding strategies including different proportion of pasture and concentrate, on carcass and meat quality traits in Uruguayan steers. Meat Sci., v.80, p.753-760, 2008.
CASTRO, A.C.; LOURENÇO JUNIOR J.B.; SANTOS, N.F.A. et al. Sistema silvipastoril na Amazônia: ferramenta para elevar o desempenho produtivo de búfalos. Cienc. Rural, v.38, p.2395-2402, 2008.

COSTA, D.A.; LOURENÇO JUNIOR J.B.; FERREIRA, G.D.G. et al. Avaliação nutricional da torta de dendê para suplementação de ruminantes na Amazônia Oriental. Amazônia: Cienc. Desenv., v.4, p.86-98, 2009.

EUCLIDES FILHO, K.; EUCLIDES, V.P.B.; FIGUEIREDO, G.R. et al. Avaliação de animais Nelore e de seus mestiços com Charolês, Fleckvieh e Chianina, em três dietas. Características de carcaça. Rev. Bras. Zootec., v.26, p.73-79, 1997.

FELICIO, P.E. Fatores que influenciam na qualidade da carne bovina. In: PEIXOTO, A.M.; MOURA, J.C.; FARIA, V.P. (Org.). Produção de novilho de corte. Piracicaba: FEALQ. p.79-97, 1997.

FRANZOLIN, R.; SILVA, J.R. Níveis de energia na dieta para bubalinos em crescimento alimentados em confinamento. 2. Características de carcaça. Rev. Bras. Zootec. v.30, p.1880-1885, 2001.

GESUALDI JÚNIOR, A.G.; PAULINO, M.F.; VALADARES FILHO, S.C. et al. Níveis de concentrado na dieta de novilhos $\mathrm{F} 1$ Limousin $\mathrm{x}$ Nelore: Características da carcaça. Rev. Bras. Zootec., v.29, p.467-1473, 2000.

GIGLI, S.; FAILlA, S.; CARRETTA, A. et al. Growth of young bulls: liveweight, carcass and meat. In: WORLD BUFFALO CONGRESS, 4., 1994, São Paulo, Proceedings... São Paulo: Associação Brasileira de Criadores de Búfalos/FAO/FINEP, v.2, p.18-20, 1994.

INSTITUTO brasileiro de geografia e estatísticaIBGE. Sidra - Banco de dados agregados. Brasília: IBGE. Disponível em: http://www.sidra.ibge.gov.br/bda/. Acessado em: Jan 07, 2010.

JORGE, A.M.; ANDRIGHETTO, C.D.; MILLEN, D. et al. Características quantitativas da carcaça de bubalinos de três grupos genéticos terminados em confinamento e abatidos em diferentes estádios de maturidade. Rev. Bras. Zootec., v.34, p.2376-2381, 2005.

LOURENÇO JUNIOR, J.B.; GARCIA, A.R. Produção animal no bioma Amazônico: atualidades e perspectivas. Rev. Bras. Zootec., v.35, p.63-83, 2006.

LUCHIARI FILHO, A. Pecuária da carne bovina. São Paulo: A. Luchiari Filho. 2000. 134p. 
MISSIO, R.L.; BRONDANI, I.L.; ALVES FILHO, C.D. et al. Características da carcaça e da carne de tourinhos terminados em confinamento, recebendo diferentes níveis de concentrado na dieta. Rev. Bras. Zootec., v.39, p.1610-1617, 2010.

MÜLLER, L. Normas para avaliação de carcaças e concurso de carcaça de novilhos. 2.ed. Santa Maria: Universidade Federal de Santa Maria, 1987.31p.

OLIVEIRA, A.L.; VELlOSO, L.; SCHALCH, E. Carcass characteristics and yields of zebu steers compared with buffalo. In: WORLD BUFFALO CONGRESS, 3., 1991, Varna, Bulgaria. Proceedings ... Varna: The Congress, 1991. v.4, p.1019-1026.

OLIVEIRA, A.L. Búfalos: produção, qualidade de carcaça e de carne. Alguns aspectos quantitativos qualitativos e nutricionais para produção do melhoramento genético. Rev. Bras. Reprod. Anim., v.29, p.122-134, 2005.

OLIVEIRA, K.C.C.; FATURI, C.; GARCIA, A.R. et al. Supplemental feeding for buffaloes with agroindustry by-products on silvipastoral system in brazilian eastern amazon. Rev. Vet., v.21, supl.1, p.809-811, 2010.

PACHECO, P.S.; RESTLE, J.; SILVA, J.H.S. et al. Desempenho de novilhos jovens e superjovens de diferentes grupos genéticos terminados em confinamento. Rev. Bras. Zootec., v.34, p.963-975, 2005.

RESTLE, J.; KEPLIN, L.A.S.; VAZ, F.N. Características quantitativas da carcaça de novilhos Charolês, abatidos com diferentes pesos. Pesq. Agrop. Bras., v.32, p.851-856, 1997.

RESTLE, J.; VAZ, F.N.; FEIJÓ, G.L.D. et al. Características de carcaça de bovinos de corte inteiros ou castrados de diferentes composições raciais Charolês e Nelore. Rev. Bras. Zootec. v.29, p.13711379, 2000.
RESTLE, J.; VAZ, F.N.; ALVES FILHO, D.C. et al. Efeito da suplementação energética sobre a carcaça de vacas de diferentes idades, terminadas em pastagem cultivada de estação fria sob pastejo horário. Rev. Bras. Zootec., v.30, p.1076-1083, 2001.

RIBEIRO, T.R.; PEREIRA, J.C.; OLIVEIRA, M.V.M. et al. Carcass characteristics of Holstein veal calves fed diets with different levels of concentrate. Rev. Bras. Zootec. v.30, p.2154-2162, 2001.

SILVA, M.E.T.; FLEMMING, J.S.; MARTINE, J.L. et al. Características quantitativas e qualitativas de carcaças de búfalos (Bubalus bubalis L.) alimentados com diferentes proporções de volumoso e concentrado em regime de confinamento no Brasil. Rev. Acad. Cienc. Agr. Amb., v.4, p.102-105, 2006.

VAZ, F.N.; RESTLE, J.; SILVA, N.L.Q. et al. Nível de concentrado, variedade da silagem de sorgo e grupo genético sobre a qualidade da carcaça e da carne de novilhos confinados, concentrado, variedade da silagem de sorgo. Rev. Bras. Zootec., v.34, p.239-248, 2005.

VAZ, F.N.; RESTLE, J.; BRONDANI, I.L. et al. Estudo da carcaça e da carne de bubalinos Mediterrâneo terminados em confinamento com diferentes fontes de volumoso. Rev. Bras. Zootec., v.32, p.393-404, 2003.

WHEELER, T.L.; KOOHMARAIE, M.; SHACKELFORD, S.D. Standardized Warner-Bratzler shear force procedures for meat tenderness measurement. Clay Center: Roman L. Hruska U.S. MARC. USDA. 1995. 7p. 